\title{
Job satisfaction of women employees of the public sector of Afghanistan
}

\author{
Arezo Mehrzad and Pierre Rostan \\ Business, American University of Afghanistan, Kabul, Afghanistan
}

\begin{abstract}
Purpose - This paper focuses on job satisfaction of women employees in the public sector of Afghanistan and identifies factors and challenges influencing women's job satisfaction in their workplace.

Design/methodology/approach - The survey data were gathered from 92 employees working at the Ministry of Finance at different position levels.

Findings - The findings indicate that women employees highly prioritize salary increment and job promotion as their main job satisfaction factors while mentioning low salary, delay in salary payment and unsuitable workplace as the biggest challenges. Among recommendations, the research suggests to launch workshops for male employees to improve their behavior with women employees in the workplace, to promote employees based on their merit regardless of gender, to standardize salary scales, to develop a chart of female rights highlighting how they should be treated in their workplace and to support the female employees by eliminating gender discrimination and providing a secure work environment free of gender bias.

Social implications - The findings and recommendations may help public sector organizations as well as the private sector of Afghanistan to improve women employees' job satisfaction.

Originality/value - This article represents an added value for the literature which lacks references about the satisfaction of women working in the public sector of Afghanistan.
\end{abstract}

Keywords Job satisfaction, Work environment, Women workforce

Paper type Research paper

\section{Introduction}

Afghanistan is a traditional country with a male-dominated society and is one of the least developed countries that have not yet succeeded in bringing major administrative reforms within the work environment in the public sector for both men and women employees (Yusufzada and Xia, 2019). The public sector is a part of the economy that is controlled by the state. Public activities are carried out to produce goods and services such as infrastructure (telecommunication, water supply, electricity, bridges, roads, tunnels, etc.) or security and public transportation. The private sector of Afghanistan has not been highly developed, most public services are provided by Afghan governmental agencies. The Afghan state agencies are mainly formed by ministries, independent authorities and general directorates. According to Afghanistan (National Statistics and Information Authority, 2019, pp. 31-32), in 2018, the total number of employees including women who worked in the public sector reached 404,151 , not including the military staff which belongs to the security sector. According to the

(C) Arezo Mehrzad and Pierre Rostan. Published in PSU Research Review. Published by Emerald Publishing Limited. This article is published under the Creative Commons Attribution (CC BY 4.0) licence. Anyone may reproduce, distribute, translate and create derivative works of this article (for both commercial and non-commercial purposes), subject to full attribution to the original publication and authors. The full terms of this licence may be seen at http://creativecommons.org/licences/by/4.0/ legalcode.

The authors would like to specially thank the Senior Management and the Human Resources Department of the Ministry of Finance of Afghanistan for their support at various phases of this research.
Job satisfaction

of women

employees

Received 2 June 2021

Revised 19 October 2021 Accepted 21 November 2021 
2018 Statistical Yearbook by National Statistics and Information Authority of Afghanistan, $78 \%$ of the employees of the public sector were male and $22 \%$ were female.

This study targets the Ministry of Finance which is among the top five public agencies with the highest rate of women's labor force. The substantial role of the Ministry of Finance as a public agency among other Afghan governmental organizations is remarkable. The Ministry of Finance is one of the key state authorities and is responsible for implementing the Budget Law, macroeconomic projections, budgets, revenues, customs, treasury and accounting. In total, 7,547 employees were working with the Ministry of Finance in 2018 of which 6,941 (92\%) were males and 606 (8\%) were females (National Statistics and Information Authority, 2019). Women being considered as one of the most vulnerable groups in Afghanistan's traditional and patriarchal society are facing daily challenges in their personal and professional lives. They have been victims of numerous acts of violence by terrorist organizations for the past three decades. The last episode of cowardice against women that displayed beastly doggedness was the killing of at least 58 people (mostly girls) and more than 100 injured in a bomb attack on girls leaving their secondary school in west Kabul in May 2021 during the Holy month of Ramadan (Graham-Harrison, 2021). In May 2020, the Kabul maternity hospital of MSF (Médecins Sans Frontières, Doctors Without Borders) was attacked by three gunmen who murdered in cold blood eleven pregnant women, three of them in the delivery room with their unborn babies; in addition, they injured five mothers, two newborn babies, three MSF staff, killed two babies and a MSF midwife (Médecins Sans Frontières, 2020). In history, such odious crimes were reported by the chronicler Ibn Al-Athir with reference to the Mongol onslaught into the lands of Islam during the 13th century: "these Tatars spared none, slaying women and men and children, ripping open pregnant women and killing unborn babes” (Simons, 2003, p. 169). Unfortunately, in the 21st century, the Afghan society has to deal almost weekly with these barbaric acts of odious cruelty that violate the fundamental principles of Islam whose Sharia commands the respect of human life. Thus, the environment of Afghan women is insecure and subject to violence and threats, particularly for those who are participating in public life. As the evidence shows, Afghan women were killed for working outside home and holding a job because this situation is regrettably considered in Afghanistan a desecration to traditional practices and in conflict with Islam. In January 2021, two female judges working for the Afghan Supreme Court were shot and killed in Kabul by armed men who attacked their vehicle (Hashimi, 2021). Other examples of violence against women are the parallel stories of two dominant Afghan women, Lieutenant-Colonel Malalai Kakar, head of Kandahar's Police department of crimes against women, murdered by a terrorist group in 2008 and MP Sitara Achakzai, a leading Afghan women's rights activist and a member of the regional parliament of Kandahar murdered as well in 2009. Their crime was to be women participating in public life (UNAMA, 2009). In the past, in a traditional Afghan lifestyle, women were expected to play their role of "homemakers" but in recent decades the situation has virtually changed and their role has been expanded from "homemaker" to "homemaker and comfort provider". It means that alongside staying home and taking care of children, women started working outside and participated in public life and in such a way they played a dual role (Saxena et al., 2009). Since the issue of gender equality has been raised, the world including Afghanistan has increasingly started focusing on the study of challenges and threats which Afghan women have faced. By identifying the factors harmful to women, the Afghan government as well as other bodies who are fighting for women's rights will be able to implement a course of actions for heading off the threats. The diminution of gender inequality in the workplace is one salutary action that will lead to job satisfaction of women employees.

This study examines job satisfaction of women employees of the Ministry of Finance of Afghanistan, particularly addressing: (1) What are the determinants of Afghan women's job satisfaction in the Ministry of Finance as a public agency? and (2) Which challenges are facing Afghan women in their workplace within the public sector causing dissatisfaction at 
work? Section 2 reviews the literature related to women workforce and job satisfaction. Section 3 presents the methodology. Section 4 gathers the findings and recommendations, and Section 5 concludes.

\section{Literature review}

The literature review focuses on relevant topics related to the impact of the workplace on women's job satisfaction in public organizations.

\subsection{Women workforce}

In Afghanistan, women have shown in recent decades that they can encourage and empower employees (subordinates) better than men by sincerity in duty and using managerial skills in an effective way (Sarker, 2019). The participation of Afghan women in the government and the public sector is very negligible because of the cultural, security issues, family, abuse committed by men and unsafe work environment (Yusufzada and Xia, 2019). Hence, providing a safe and free of violence workplace by Afghan governmental authorities will remove the concerns of most Afghan families to allow their women to work in the public sector. In Afghanistan, the media regularly talk on women's sexual harassment in the public sector discouraging Afghan women to work for governmental agencies. The later need to strive to provide a safe workplace for women employees and eliminate any kind of violence, psychological or physical, against them.

\subsection{Job satisfaction}

2.2.1 The importance of job satisfaction in an organization. Mbah and Ikemefuna (2012) have linked job satisfaction with positive attitude of employees. Organizations should realize that by identifying the effective factors which are necessary for their women staff, and providing them to the women can make their employees feel satisfied and prevent them from losing talented and skilled employees.

2.2.2 The determinants of job satisfaction. The physical aspect of a work environment is known as a key factor impacting job satisfaction within it. The physical facets of a workplace environment not only affect job satisfaction but also comfort, morale of employee, health and safety, and concentration (Bachner, 2000). According to Rajan and Joh (2015), a long range of factors affecting employees' job satisfaction includes transparent approach of promotion system within the organization, pay and benefit, the quality of the working condition to leadership and social relationships.

2.2.3 The impact of work environment on job satisfaction. As studies show, a conductive workplace influences an employee's decision on continuing job with her/his employer. For example, Ibneatheer et al. (2021) found that emotional, cultural and ethical internal processes of Afghan business leaders are drivers that enhance employees' job satisfaction in the workplace. Adversely, a toxic workplace caused by low salary and wages, work relationships, job stress, inadequate opportunities will lead to women's dissatisfaction and discourage women to work with governmental organizations (Yusufzada and Xia, 2019). Rahman et al. (2012) used a sampling design to identify the factors affecting job satisfaction of female employees working in the banking sector in Bangladesh. The study concluded that important factors such as satisfied provision salary increment, available opportunities for work, adequate remuneration for work, training program regularly, motivation to work, recognition for good work, satisfied space available lunch, satisfied incentives and benefits, satisfied environment, and breaks and prayer highly affecting women's job satisfaction. Bojadjiev et al. (2015) found that out of eleven work environment factors (work perception, salary satisfaction, advancement, and growth, mission and core values of an organization, responsibility, autonomy, supervisor and colleague relationships, great feelings about the organization, work/life balance, development and training), nine of them were key factors for women employees, promotion and opportunities having a lower priority compared to their male co-workers. Al Zabir et al. (2018) studied the 
effects of job satisfaction of women working in different public and private institutions of Sylhet city, Bangladesh; and $60 \%$ of total women respondents were satisfied with factors such as equally distributed workload; emergency leave; maternity leave; good relationship with the immediate supervisor; pay and benefits; and excellent communication with colleagues and supervisors affecting women employees' job satisfaction in public and private organizations. On the contrary, most of female employees were dissatisfied with child care facilities, sexual harassment, transportation facilities and the opportunity for career development.

The literature review above has provided a reasonable understanding of key factors influencing women employees' job satisfaction in their work in the public sector in various countries.

\section{Methodology and research design}

This paper analyses the impact of the work environment on women employees' job satisfaction in the public sector of Afghanistan. The research assumption is that the Ministry of Finance will be an appropriate proxy of the public sector in Afghanistan.

\subsection{Participants}

The study surveyed the work status of female employees working with the Ministry of Finance in different capacities such as deputy minister, general director, manager, specialist, officer, assistant and intern. The criteria for participants' eligibility in this research were (1) being Afghan; (2) being female; (3) being employee of the Ministry of Finance; (4) ability to know Dari or Persian; (5) at least 20 years old (no limitation for the maximum age, 40+); (6) working in any position within the Ministry of Finance; (7) being in any education level; and (8) willingness to participate in filling out the three-page questionnaire. Since most participants were educated, it helped having access to rich data because respondents could better understand the questions and better analyze their work environment.

\subsection{Sampling}

The sampling frame was the total number of female employees working with the Ministry of Finance that has been reported of 606 in 2018 (National Statistics and Information Authority, 2019). The sample included 100 employees $(N=100)$ working in different departments, positions and age range, which constituted approximately $17 \%$ of all female employees of the Ministry of Finance. Snowball and convenience sampling techniques were selected based on the partial work relationship existing with the female staff in the Ministry of Finance making it easier to obtain a higher response rate in a short time. In addition, the Ministry of Finance includes many departments spread out in several areas of Kabul, so snowball was an appropriate technique to deal with the geographical challenge.

\subsection{Research site}

A 2019 report shows that the Ministry of Finance has approximately 7,547 employees of which 6,941 are male and 606 are female (National Statistics and Information Authority, 2019). Table 1 illustrates the proportion of contract versus government employees working at the Ministry of Finance in 2018.

The Ministry of Finance is located in multiple areas in Kabul. The Ministry has a mosque where a majority of women employees (approximately 60-70) come daily. For this reason, most of the questionnaires were distributed in the mosque, a strategic location to obtain female staff's opinion on their job satisfaction without leaving the mosque with the questionnaire unanswered. Furthermore, the site was ideal for the researchers to implement the convenience technique.

\subsection{Phases}

The study comprised five phases (1) situation analysis; (2) design; (3) implementation; (4) data collection and (5) evaluation. 
3.4.1 Situation analysis. The fact that one of the researchers is an employee of the Ministry of Finance made the survey well accepted by her community, environment, site and policies. It is worth mentioning that interpersonal relationship between female employees worked excellently in Afghanistan.

3.4.2 Design. The researchers selected a research design presented in Figure 1 by identifying relevant factors such as research purpose, context, theoretical model, research procedures and techniques which were highlighted by Blanche et al. (2007).

3.4.3 Implementation. The objectives were (1) to prepare the self-administered questionnaire and the questions were finalized after the supervisor's confirmation; (2) to obtain written approval from the HR department to distribute self-administered questionnaires among the female employees of Ministry of Finance; and finally (3) to distribute the questionnaire through two approaches each convenience and snowball data; and (4) to collect data.

3.4.4 Data collection. The primary method for data collection was the self-administered questionnaire containing structured questions. Mimicking past scholars inquiring about job satisfaction, the questionnaire included Likert scale, dichotomous (Yes or No) questions, point systems, checklists, true/false and forced choice answers.

3.4.5 Evaluation. This was an overall methodological process evaluation assessing to what extent plans in terms of the pre-set goals and objectives were implemented.

\subsection{Questions}

The 15 questions presented through a structured and semi-structured self-administered questionnaire focused on the following: (1) what are the determinants of Afghan women's job satisfaction in the Ministry of Finance as a public agency? and (2) which challenges are facing Afghan women in their workplace within the public sector causing dissatisfaction at work?

\subsection{Ethical consideration}

The researchers obtained consent from Human Resources Department of the Ministry of Finance, Managers and participants. Respondents were guaranteed confidentiality and anonymity of their answers.

\section{Data analysis and findings}

The study focused on the work environment and women employees' job satisfaction in the public sector of Afghanistan. This research identifies and analyzes the factors and challenges of the workplace affecting women employees.

\subsection{Participants}

The survey participants (women employees of the Ministry of Finance) and the surveyor are Afghans; the questionnaire was translated into Dari, one of the official languages of Afghanistan in order to make participants able to fully understand the questions.

Figure 1.

Factors of research design

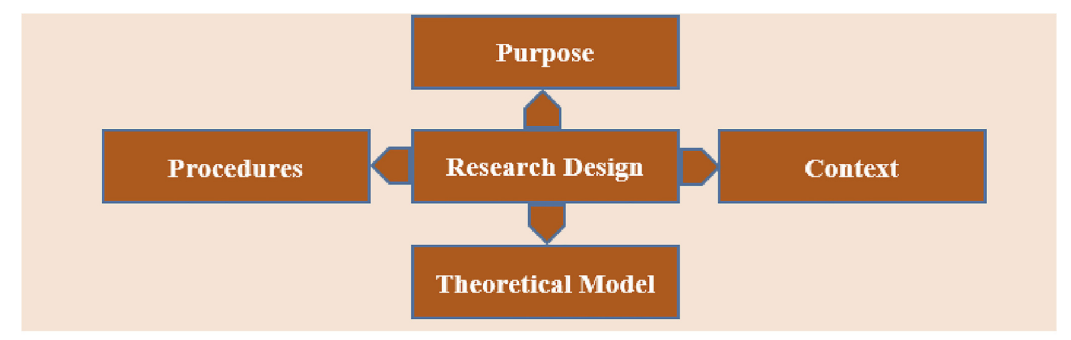

Source(s): Own elaboration 
The sample represented women with various education backgrounds and different work spans in the public sector. The Ministry of Finance employs two types of employees, (1) governmental employees and (2) contract employees. Each type has its own advantages and disadvantages, with a different perspective about the work environment. The primary data were collected from both categories shown in Table 4. In addition, the sample gathered opinions of women employees with different job titles (see Figure 2).

\subsection{Survey questions}

The first six questions focused on the participants' demographic questions that asked for basic information such as age, gender, ethnicity, or income" (Jackson, 2008, p. 90). The answers of the demographic questions revealed which categories of women workforce were facing challenges.

Most of the respondents belonged to the age group between 26 and 30-year old, regarding to marital status, 46 respondents were unmarried, 42 married and only 3 of the participants were divorced. Table 2 provides details about the respondents' age and marital status.

According to the demographic information, $92 \%$ of the respondents were undergraduate and graduate indicating that respondents, being educated, were able to understand the content of the questionnaire. Most women employees who filled the questionnaire have been working in the Ministry of Finance for more than three years. The respondents were therefore familiar with the environment and have being facing opportunities and challenges that the Ministry of Finance could offer for a reasonable period of time. The details are presented in Table 3.

4.2.1 Survey question 7. I am satisfied with my job in the Ministry of Finance. The answer for this question illustrated in Figure 3 ranged from 1 to 5 while "1 indicates Strongly Disagree" and "5 indicates Strongly Agree". From a total of 92 responses received, 5 employees strongly disagreed and 20 employees strongly agreed with the statement. All five employees were governmental employees (not contract employee) who had lower salary compared to their peers who were contract employees. The highest degree that they have received was a bachelor degree, 4 of them have been working as assistants and 1 of them was an officer. They have been working in lower positions. Each belonged to a different range of

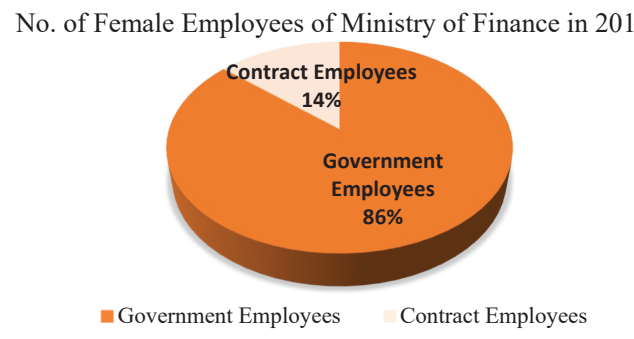

Source(s): National Statistics and Information Authority, 2019

\begin{tabular}{|c|c|c|c|c|c|c|}
\hline Age & $\begin{array}{c}20-25 \\
26\end{array}$ & $\begin{array}{c}26-30 \\
32\end{array}$ & $\begin{array}{c}\text { Age gr } \\
31-35 \\
13\end{array}$ & $\begin{array}{c}36-40 \\
10\end{array}$ & $\begin{array}{c}40 \text { or older } \\
11\end{array}$ & \multirow{2}{*}{$\begin{array}{r}\text { Table } 2 . \\
\text { A summary of age and } \\
\text { marital status of } \\
\text { respondents }\end{array}$} \\
\hline Marit & & $\begin{array}{c}\text { Unmarried } \\
46\end{array}$ & & & $\begin{array}{c}\text { Divorced } \\
3\end{array}$ & \\
\hline
\end{tabular}

Job satisfaction of women employees

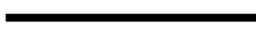

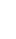


age and each listed three challenges that they met in the workplace: inappropriate behavior of colleagues (mainly male colleagues); low salary; small office space; less attention to female employees; lack of promotion; delay in salary payment and lack of corporation among the colleagues within an office. On the other hand, from 20 employees who were strongly satisfied with their job, 16 of them were government employees and 4 of them were contract employees. These 20 respondents hold different positions such as, director, manager, specialist, officer, assistant, supporting staff and intern.

As Figure 3 illustrates, the most frequent answer was "Agree" selected by $47 \%$ of whole participants. The majority of them belonged to 26-30 category of age, having a master degree and having been working with the Ministry of Finance for one to two years.

4.2.2 Survey question 8. The work environment of the Ministry of Finance is friendly and free of gender discrimination. The answer for this question illustrated in Figure 4 also ranged from 1 to 5 as " 1 denotes Strongly Disagree" and " 5 denotes Strongly Agree". From total of 92 responses received, 9 employees strongly disagreed and 12 employees strongly agreed with the statement. The 9 employees who marked "strongly disagree" for the statement have been working in low positions-officer and assistant level. It suggested that they were not treated well by their colleagues because of their junior position. $78 \%$ of them were employees with a seniority of 5-6 years or more than 6 years with the Ministry of Finance. It means that with

Table 3.

A summary of qualification and job experience of the respondents

\begin{tabular}{lccccc}
\hline & Associates degree & Bachelor degree & Graduate degree & \multicolumn{2}{c}{ Other } \\
Education & 3 & 65 & 20 & \multicolumn{2}{c}{4} \\
\hline Work experience & Less than 1 year & $1-2$ years & $3-4$ years & $5-6$ & $6+$ \\
& 5 & 23 & 23 & 18 & 23 \\
\hline
\end{tabular}

\section{Table 4.}

A summary of employment type and job title of the respondents

\begin{tabular}{cc}
\hline & Governmental employee \\
Employment type & 73
\end{tabular}

Job title

Director
4
Assistant
34

34

$\begin{array}{ccc}\text { Manager } & \text { Specialist } & 18 \\ 17 & 10 & \text { Officer } \\ \text { Supporting staff } & \text { Intern } & 19 \\ 4 & 3 & \text { Other } \\ & & 1\end{array}$

Figure 3.

I am satisfied with my job at the Ministry of Finance
Answered: 91 Skipped: 1

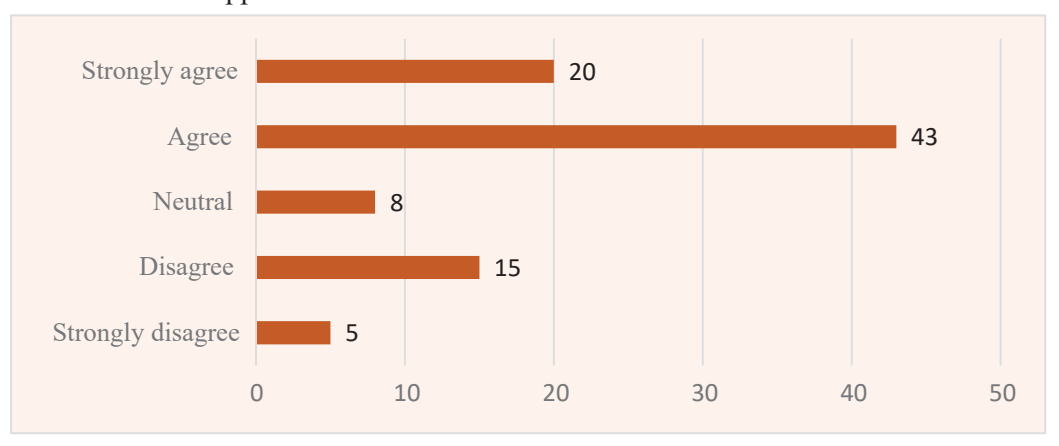

Source(s): Own elaboration 
such a long period of time they were fully familiar with environment of the Ministry including opportunities and challenges. Meanwhile, these employees wrote down inappropriate behavior of male colleagues as a main challenge within the workplace.

As Figure 4 illustrates, the preferred answer was "somewhat agree" selected by $37 \%$ of the participants. The majority of them were government employees however they received lower salary than the contract employees, their first priority being a secure and healthy workplace.

4.2.3 Survey question 9. Since working in the Ministry of Finance, have you ever faced any challenge/s in the work environment? It was a dichotomous question with two possible answers, Yes and No, illustrated in Figure 5. This question was immediately followed by a question where respondents were asked to list three challenges of their workplace. In total, 43 employees answered "Yes" while the remaining, 49, employees answered "No."

4.2.4 Survey question 10. Please, specify the top three challenges in your work environment. The answers are illustrated in Figure 6. This was an open-ended question directly related to the research question, i.e. which challenges are facing Afghan women in their workplace within the public sector causing dissatisfaction at work? 34 participants (out of 92) described the challenges that they faced in the workplace. These participants did not belong to a particular category of age, marital status or education level.

Figure 6 represents the main challenges mentioned by $56 \%$ of female employees where low salary, inequality in salary and delay in salary payment are the top challenges. Unsuitable working place, and inappropriate behavior of colleagues follow then lack of attention and support for women employees' rights.

Answered: 92 Skipped: 0

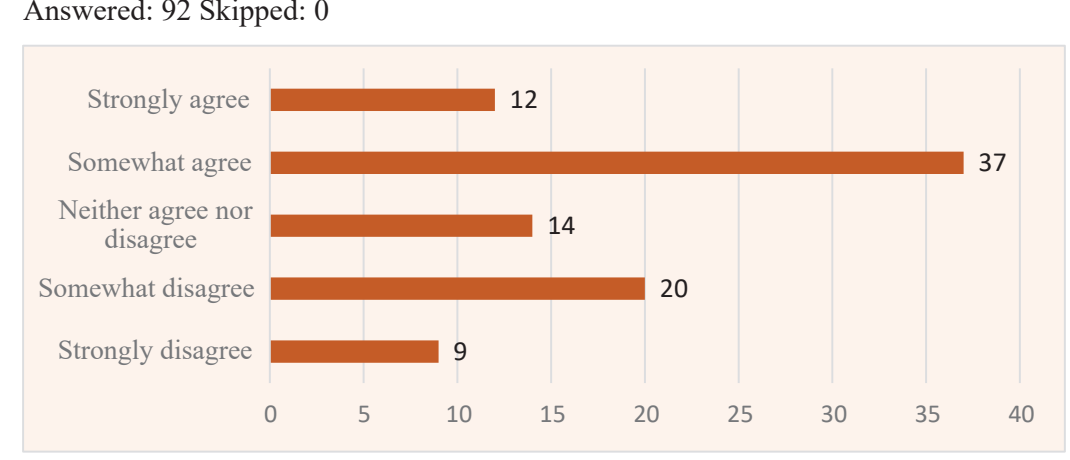

Source(s): Own elaboration

Answered: 92 Skipped: 0

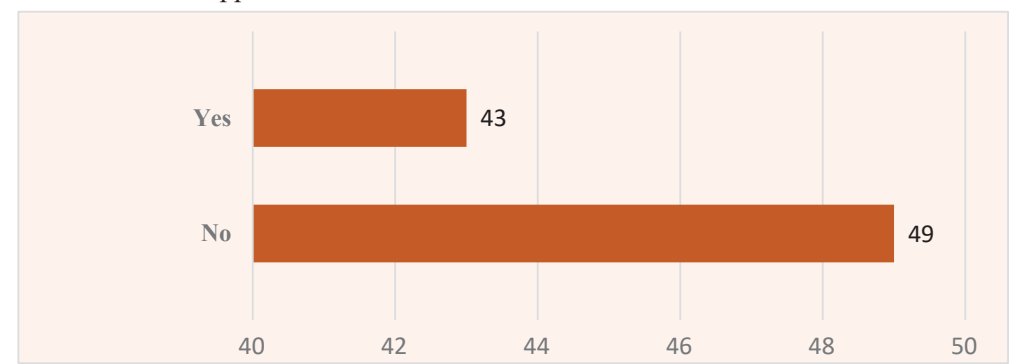

Source(s): Own elaboration
Job satisfaction of women employees
Figure 4.

The work environment in the Ministry of Finance is friendly and free of gender discrimination
Figure 5.

Employees answer if since working in the Ministry of Finance, they have ever faced any challenge/s in the work environment? 


\section{PRR}

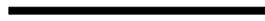

Figure 6.

Workplace challenges of women employees in the ministry of finance
Answered: 34 Skipped: 0

\section{Frequency Distribution of The Challenges}

Low salary and delay in salary payment

Unsuitable workplace \& Inappropriate behavior

Lack of attention \& Support

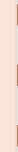

Lack of transportation facilities

Gender discrimination

Lack of management

Lack of promotion

Lack of cooperation

Office space \& lack of acess to computers \& stationary

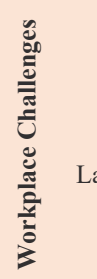

Security threats

Lunch problem

Lace of transparancy in employement process

Job security

Lack of financial aid in education tution

\section{(1)}
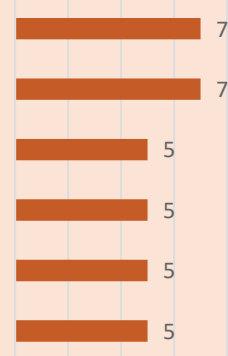

Lack of health clinic, medicine \& doctor

Inequality in allocation of abroad trainings

Uninformed shifting of employees

Load of work
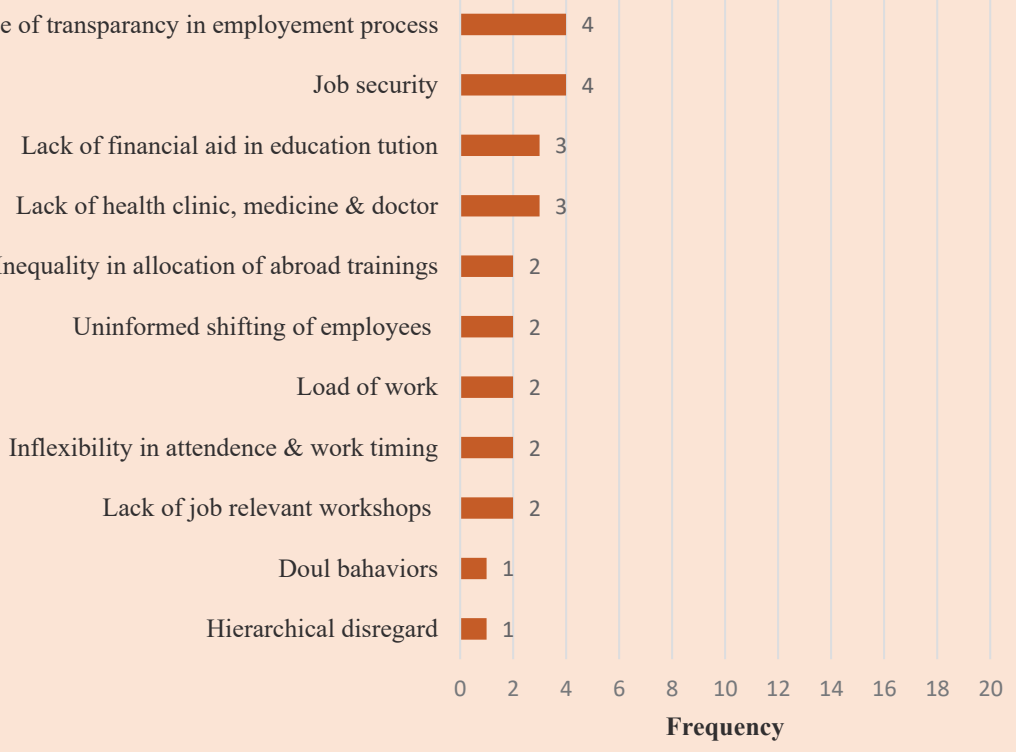

Source(s): Own elaboration

4.2.5 Survey question 11, part (a). Has there been any time during your work when you have tempted to leave the Ministry of Finance? If yes, (a) please explain briefly the circumstances, and (b) explain why you decided to continue. This was an open-ended twofold question to seek detailed information about the satisfaction of employees in their work environment. 
Of the 92 respondents, 43 answered "Yes", 10 of them did not explain the circumstances and only wrote down the reason they decided to continue job with the Ministry of Finance. The remaining participants $(77 \%)$ provided answers for both parts. The reasons provided by participants tempting them to leave the Ministry of Finance are illustrated in Figure 7 by order of frequency.

4.2.6 Survey question 11, part (b). In order to obtain a more detailed information for question 11, one more statement was added. In part (b), participants were asked to explain why they decided to continue working in the Ministry of Finance if they had been tempted to leave the Ministry. In total, 43 women employees revealed the following reasons that made

Answered: 33 Skipped: 10

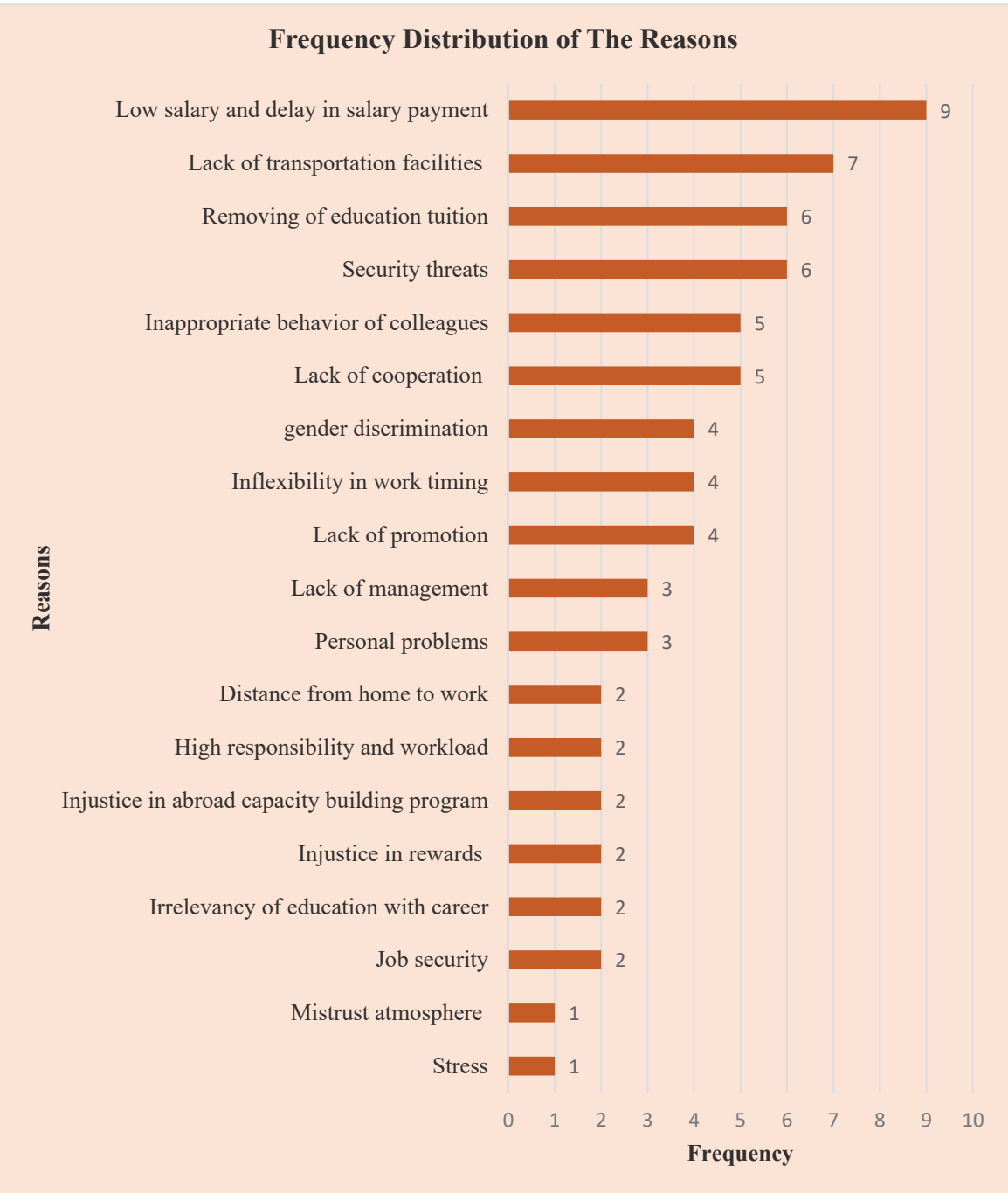

Source(s): Own elaboration

Figure 7. Reasons tempting employees to leave the Ministry of Finance 
them continue working with the Ministry of Finance: commitment and interest in the job; financial problems; difficulty in obtaining another job; getting used to the workplace; until finding another job; economic self-sufficiency; capacity building and available opportunity for promotion in higher positions; the relevancy of education with the current career; fixing transportation problem; good position and salary; emphasis of international institutions on continuing of work and extension of the employment contract of women employees; changes in the decision-making levels and suitable workplace.

4.2.7 Survey question 12. Name three existing factors in your workplace that you are most satisfied with. This is an open-ended question. This question aimed at answering the first research question of this study-what are the determinants of Afghan women's job satisfaction in the Ministry of Finance as a public agency? From 92 collected questionnaires, there were 9 skipped answers. Respondents mentioned the following factors: cooperation and teamwork; suitable and friendly environment; being a governmental and recognized agency; providing oversea trainings; job promotion, rewards and supporting the rights of female employees; pension, overtime and permanent employment; physical location of the Ministry of Finance which is in the central of Kabul and close to the car/bus stations; childcare facilities and Mosque; youth recruitment; good position and salary compared to most other state agencies; flexibility in work timings; access to high speed Internet; obedience of hierarchy; acceptance of each other; standardization of taxation by implementation of (SIGTAS); capacity building programs; access to lunch inside the Ministry (however it is not much healthy but no need to go outside for having lunch) and ignoring ethnic prejudices.

4.2.8 Survey question 13. What could the Ministry of Finance do to enhance your job satisfaction as an employee? This question was an open-ended question. Almost all participants answered the question. Their suggestions are part of the recommendations section below. Most of them do not need much financial resources to be implemented and only require some revisions of the existing procedures.

4.2.9 Survey question 14. Rank from 1 to 6 the following factors in term of priority for your job satisfaction. This question was massively answered by 91 participants with only one who skipped it. The respondents were asked to rank from 1 to 6 the following options/factors based on their priority: (1) salary increment; (2) job promotion; (3) policy advocating the female employees' rights working in the ministry of finance; (4) healthy environment; (5) flexibility in working hours; (6) supervisor support. The first priority of women employees in relation to job satisfaction was "salary increment" ranked " 1 " by 35 participants. The second priority from the perspective of women employees was "job promotion" ranked " 2 " by 22 employees while the lowest priory of the female employees was "flexibility in working hours" ranked " 6 " by " 20 " respondents.

\subsection{Regression analysis}

To refine the data analysis, the authors run an OLS regression. Having a sample with more than 30 observations (i.e. 92 observations) ensures normality of the distribution. The dependent variable is job satisfaction that is converted into values from zero to one: I am satisfied with my job at the Ministry of Finance (refer to Figure 3), strongly disagree gets zero to strongly agree that gets 1 , with intermediate answers from 0.25 (disagree) to 0.5 (neutral) to 0.75 (agree). The nine independent variables that may impact the satisfaction of the employees are the following: (1) friendly environment and free of gender discrimination (refer to Figure 4 , from $0 \%$ to $100 \%$ with intermediate values of $25 \%, 50 \%, 75 \%$ ), binary values ( 1 if yes, else 0 ) for the following variables: (2) "have you ever faced any challenge/s in the work environment?", (3) low salary, (4) bad behavior of colleagues, (5) lack of support from the management, (6) lack of transportation to go working, (7) gender discrimination, (8) lack of management and (9) lack of promotion. The six control variables are the following: (1) age of the employee ( 22.5 which is the central value of the age interval from 20 to $25,28,33$, 38 and 45 when older than 40); (2) marital status ( 1 if married, else 0 ); (3) education (0 for associate degree 
and others, 0.5 for bachelor's degree, 1 for graduate degree); (4) work experience ( 0.5 when less than 1 year, 1.5 when $1-2$ years, 3.5 when $3-4$ years, 5.5 when $5-6$ years, 7 when more than 6 years); (5) government employee (1 if yes, else 0); (6) job title (director gets 1, manager 0.9, specialist 0.75 , officer 0.6 , assistant 0.45 , supporting staff 0.3 , intern 0.15 , other 0 ).

The output of the OLS regression is found in Table 5. Three variables explain job satisfaction of female employees based on this model: (1) job title, the higher being the position of the employee in the hierarchy the greater job satisfaction; (2) challenges; when an employee has ever faced any challenge/s in the work environment, job satisfaction is negatively impacted; (3) low salary; when an employee is concerned about her low salary, job satisfaction is negatively impacted. The other variables have no significant impact on job satisfaction with a $p$-value greater than the level of significance of $5 \%$. Overall, $83 \%$ of the variance of job satisfaction is explained by the variance of the model. As identified by Tharu (2019), variables such as pay facilities, working environment, training courses, encouragement factors and motivation factors have significant impact on job satisfaction of the employees at 5\% level of significance. The present article confirms that salary and challenges faced in the working environment by the employee have an impact on job satisfaction. The job title may be linked to the motivation factor recalled by Tharu since getting promotion motivates the employee in the accomplishment of her task.

Summary output

\begin{tabular}{lc}
\hline Regression statistics & \\
Multiple $R$ & 0.929038238 \\
R square & 0.863112048 \\
Adjusted $R$ square & 0.836094689 \\
Standard error & 0.119997788 \\
Observations & 92 \\
\hline
\end{tabular}

\begin{tabular}{|c|c|c|c|c|}
\hline ANOVA & SS & MS & $F$ & Significance $F$ \\
\hline \multirow{4}{*}{$\begin{array}{l}\text { Regression } \\
\text { Residual } \\
\text { Total }\end{array}$} & 6.900205558 & 0.460014 & \multirow[t]{3}{*}{31.94657} & \multirow{3}{*}{$1.08953 \mathrm{E}-26$} \\
\hline & 1.094359659 & 0.014399 & & \\
\hline & 7.994565217 & & & \\
\hline & Coefficients & Standard error & $t$ stat & $p$-value \\
\hline Intercept & 0.511461161 & 0.081181905 & 6.300187 & $1.77 \mathrm{E}-08$ \\
\hline Age & 0.00141314 & 0.002675387 & 0.5282 & 0.598899 \\
\hline Married & -0.020237236 & 0.026128394 & -0.77453 & 0.44102 \\
\hline Education & 0.010297332 & 0.052359221 & 0.196667 & 0.844613 \\
\hline Work experience & 0.007720451 & 0.012360634 & 0.6246 & 0.534104 \\
\hline Government employee & -0.010888282 & 0.055075156 & -0.1977 & 0.843809 \\
\hline Job title & 0.393478568 & 0.093245772 & 4.219801 & 6.69E-05 \\
\hline Friendly environment & -0.011748312 & 0.043384914 & -0.27079 & 0.787285 \\
\hline Challenges & -0.20800241 & 0.033319083 & -6.24274 & $2.26 \mathrm{E}-08$ \\
\hline Low salary & -0.355430817 & 0.055276561 & -6.43005 & $1.02 \mathrm{E}-08$ \\
\hline Bad behavior & 0.013871979 & 0.04005869 & 0.346291 & 0.730081 \\
\hline Lack of support & -0.00388599 & 0.037331936 & -0.10409 & 0.91737 \\
\hline Lack of transportation & 0.070034589 & 0.042203688 & 1.659442 & 0.101148 \\
\hline Gender discrimination & 0.035061622 & 0.048223789 & 0.727061 & 0.469422 \\
\hline Lack of management & 0.071303832 & 0.052630182 & 1.354809 & 0.179492 \\
\hline Lack of promotion & 0.014421788 & 0.049931232 & 0.288833 & 0.773496 \\
\hline
\end{tabular}

Table 5. OLS regression output 
The three most important factors affecting women employees' job satisfaction in their workplace at the Ministry of Finance are (1) salary increment, (2) job promotion, and (3) policy advocating female employees' rights. As asserted by Rajan and Joh (2015), a long range of factors affecting employees' job satisfaction includes transparent approach of promotion system within the organization, pay and benefit, the quality of the working condition to leadership and social relationships.

On the other hand, the three main challenges that women employees at the Ministry of Finance are facing within their workplace are (1) low salary; (2) unsuitable workplace and inappropriate behavior of co-workers; and (3) transportation facilities. As confirmed by Yusufzada and Xia (2019), a toxic workplace caused by low salary and wages, work relationships, job stress, inadequate opportunities will lead to women's dissatisfaction and discourage women to work with governmental organizations.

Based on the answers to the questionnaire, newly hired employees with updated knowledge are better able to adapt to the workplace within the Ministry of Finance as it is assumed that fresh degree-holders are more familiar with the principles of organizational behavior. Findings show that it is possible to enhance job satisfaction level of female employees, particularly, governmental employees. In regard to Afghan culture and family limitation impacting female employees, a healthy workplace is one of the top priorities for women employees' job satisfaction. Problems and challenges have recurrently affected women employees' job satisfaction regardless of their marital status. But employees with junior positions are more vulnerable. In addition, gender discrimination can be a serious factor in the workplace. On the contrary, its absence makes female employees caring much more about a variety of challenges. According to participants' responses, a twofold situation appears: a number of factors that some employees have marked as job satisfiers become challenges for others.

Women's overall job satisfaction is associated with 21 factors such as salary increment based on seniority, request to be paid on time, priority should be given to internal recruiting when recruiting for senior positions, assign the right task to the right person, etc. To improve women employees' job satisfaction, public organizations should adjust to these suggestions. The challenges that women employees are facing in public organizations, e.g. colleagues' bad behavior, mainly males, low salary, delay in salary payment, small office space, lack of promotion and ignoring of women, should also be alleviated based on the following recommendations.

\section{Recommendations}

This research suggests the following top 10 recommendations to improve women employees' job satisfaction at the Ministry of Finance: (1) to launch workshops for male employees to improve their behavior with women employees in the workplace; (2) to promote employees based on their merit regardless of gender; (3) to standardize salary scales and to implement a fixed payroll (i.e. salary paid at the end of each month without delay); (4) to adjust the space of office rooms to the number of employees; (5) to suppress differences in salary between governmental and contract employees; (6) to write a chart of female rights highlighting how they should be treated in their workplace; (7) to support the female employees by eliminating gender discrimination and provide a secure work environment free of gender bias; (8) to focus on managerial skills and ensure that every manager is well aware of management principles so that he or she could reduce the vulnerability of subordinates who are working in junior positions by limiting the challenges that women employees could meet within the department as well as to convey any human resource management problem to the top management to take action; (9) to implement a standard for the access of employees to the abroad capacity 
building training based on their job requirement and their ability to take advantage of such programs; (10) to establish a transparent employment procedure which prioritizes the merit of the applicant.

\section{Conclusion}

Women are considered as one of the most vulnerable groups in Afghanistan's traditional and patriarchal society and are facing daily challenges in their personal and professional lives. In this context, this paper explores challenges that female employees are facing in their workplace in the public sector, more specially at the Ministry of Finance of Afghanistan, and identifies factors that affect female employees' job satisfaction. Surveying a sample of 92 women employees of the Ministry of Finance, the researchers identified factors that affect job satisfaction. The study found that (1) salary increment (2) job promotion (3) policy advocating the female employees' rights (4) healthy environment (5) flexibility in working hours and (6) supervisor support are the main factors that will improve women employees' job satisfaction. The main challenges are (1) low salary (2) unsuitable workplace and inappropriate behavior (3) lack of attention and support from supervisor and (4) lack of transportation facilities. Workplace challenges common to this paper and papers reviewed in the literature are low salary and wages; work relationships; inadequate opportunities and lack of promotion. Specific challenges identified in this study are limited workspace, inadequate lunch time and lunch facilities, and job security. An OLS regression, applied to the database and involving nine independent variables and six control variables tentatively explaining job satisfaction as the dependent variable, has shown that three variables only explain job satisfaction of employees based on this model: (1) job title, the higher being the position of the employee in the hierarchy the greater job satisfaction; (2) challenges; when an employee has ever faced any challenge/s in the work environment, job satisfaction is negatively impacted; (3) low salary; when an employee is concerned about her low salary, job satisfaction is negatively impacted.

Being the first research paper addressing Afghan women employees' job satisfaction in the public sector, specifically at the Ministry of Finance, it is expected that the findings and recommendations of this paper will help improve the work environment of women employees with the assistance of the senior management who has already sponsored this research and that these developments at the Ministry of Finance will have a snowball effect on other Ministries and public sector organizations as well as on the private sector of Afghanistan.

Finally, as mentioned in Rostan et al. (2021), the COVID-19 pandemic has seriously wounded Afghanistan. Having coped with many political and economic crises in the last two decades, Afghanistan may hopefully deal with this calamity in a more resilient manner than more developed countries. An additional event has been the Taliban takeover of Afghanistan in 2021 that has brought new challenges to Afghan female workers especially government female workers. The Taliban-appointed mayor of Kabul has told most of the city government's female employees to stay home, with work allowed only for those who cannot be replaced by men (Gannon, 2021). The intent was to send a strong signal to female workers that men have exclusive right to be active workers despite initial promises by some that Taliban would be tolerant and inclusive. This was not counting on the resilience of Afghan women. According to Andrews (2016), Afghan women are assertive, risk takers and heroic. "Afghan women do not remain traditional and subjugated. Rather, their individual journeys, and their use of traditional and non-traditional techniques to escape oppression and embrace freedom allow them to reinvent themselves as modern archetypes." In reaction to the ruling to kick out women from the workplace, just over a dozen women staged a protest outside the Women's Affairs Ministry, holding up signs calling for the participation of women in public life. The story of Afghan female workers has just begun. Men are not yet aware of the internal 
transformation of their co-workers that will propel Afghan women in the heart of the economic and political life of the country in the future.

\subsection{Research limitations and future research}

This study is not exceptional of limitations: the study was limited to female employees of the Ministry of Finance headquartered in Kabul city, hence it cannot be generalized to other taxation offices in other provinces and the research was limited by the motivation of some female employees who may have underestimated the importance and impact of such research in their life. This research may also extend to other public sectors.

\section{References}

Al Zabir, A., Mozahid, M.N., Bhuiyan, M.S., Lima, R.A. and Tasnim, A. (2018), "Factors influencing job satisfaction of women employees in public and private sectors in Sylhet City, Bangladesh", Asian Journal of Education and Social Studies, Vol. 2 No. 1, pp. 1-6, doi: 10.9734/AJESS/ 2018/41270

Andrews, A. (2016), "Defining Afghan women characters as modern archetypes using Khaled Hosseini's a thousand splendid suns and Asne Seierstad's the bookseller of Kabul", Masters Theses, p. 402, available at: https://digitalcommons.liberty.edu/masters/402.

Bachner, J.P. (2000), "Quality lighting means quality work”, ABI/Inform Database European Journal of Scientific, Vol. 33 No. 7, pp. 67-71.

Blanche, M.T., Durrheim, K. and Painter, D. (Eds) (2007), Research in Practice: Applied Methods for the Social Sciences, Paarl Print, Cape Town.

Bojadjiev, M., Petkovska, M.S., Misoska, A.T. and Stojanovska, J. (2015), "Perceived work environment and job satisfaction among public administration employees", The European Journal of Applied Economics, Vol. 121, doi: 10.5937/ejae12-8154.

Gannon, K. (2021), "Taliban tells female workers in Afghan capital to stay home”, Los Angeles Times and Associated Press, available at: https://www.latimes.com/world-nation/story/2021-09-19/ taliban-run-municipality-in-afghanistan-tells-female-workers-to-stay-home.

Graham-Harrison, E. (2021), "Blasts target school in west Kabul killing at least 58 people", The Guardian, available at: https://www.theguardian.com/world/2021/may/08/explosion-nearschool-kabul-afghanistan.

Hashimi, Z. (2021), “Afghanistan: deux femmes juges tuées par balle à Kaboul”, Le Figaro Avec AFP, available at: https://www.lefigaro.fr/flash-actu/afghanistan-deux-femmes-juges-tuees-par-ballea-kaboul-20210117.

Ibneatheer, M.U.R., Rostan, P. and Rostan, A. (2021), "Internal processes in decision-making (mental, emotional, cultural, ethical and spiritual) of Afghan business leaders", PSU Research Review, Vol. ahead-of-print No. ahead-of-print, doi: 10.1108/PRR-10-2020-0037.

Jackson, S.L. (2008), Evans, E. (Ed.), Research Methods and Statistics: A Critical Thinking Approach, 3rd ed., Cengage Learning, Boston, MA.

Mbah, S.E. and Ikemefuna, C.O. (2012), "Job satisfaction and employees' turnover intentions in total Nigeria plc. in Lagos", International Journal of Humanities and Social Science, Vol. 2 No. 14, pp. 275-287, available at: http://www.ijhssnet.com/journals/Vol_2_No_14_Special_Issue_July_ 2012/32.pdf.

Médecins Sans Frontières (2020), "Revolting attack on maternity ward kills pregnant women and babies in Afghanistan", available at: https://www.msf.org/revolting-attack-maternity-wardafghanistan.

National Statistics and Information Authority (2019), "Afghanistan statistical yearbook 2018-19", National Statistics and Information Authority, Kabul, available at: https://www.nsia.gov.af:8080/ wp-content/uploads/2019/11/Afghanistan-Statistical-Yearbook-2018-19_compressed.pdf. 
Rahman, M.M., Gupta, A.D. and Moudud -Ul-Huq, S. (2012), "Job satisfaction of female employees in financial institutions of Bangladesh: a study on selected private commercial banks in Chittagong", Global Journal of Management and Business Research, Vol. 12 No. 14, pp. 87-94, available at: https://www.researchgate.net/publication/274835174.

Job satisfaction of women employees

Rajan, P. and Joh, M. (2015), “Job satisfaction and its influence in the work environment”, International Journal of Management Research and Review, Vol. 57, pp. 554-562, available at: https://www. researchgate.net/publication/304169863.

Rostan, P., Alami, S.N., Shahab, E., Rahmani, M.A. and Azizi, S. (2021), "Challenges of islamic banking in least developed countries: the case of Afghanistan", Journal of Emerging Economies and Policy, Vol. 6 No. 2, pp. 5-19, available at: https://dergipark.org.tr/tr/download/article-file/ 1774224.

Sarker, M.N. (2019), "Public administration as an academic discipline and social science", in Global Encyclopedia of Public Administration, Public Policy, and Governance, Springer Nature Switzerland AG, Chengdu.

Saxena, R., Bhatnagar, D., Kannan, G., Gupta, V., Mavalankar, D. and Dev, R. (2009), "Gender and workplace experience", Vikalpa, Vol. 34 No. 4, pp. 79-117, available at: https:/www. researchgate.net/publication/318913147_Gender_and_workplace_experience.

Simons, G. (2003), Iraq: From Sumer to Saddam, Springer, Berlin, 978-1403917706.

Tharu, R. (2019), "Multiple regression model fitted for job satisfaction of employees working in saving and cooperative organization", International Journal of Statistics and Applied Mathematics, Vol. 4 No. 4, pp. 43-49, doi: 10.22271/maths.

UNAMA (2009), Silence is Violence: End the Abuse of Women in Afghanistan, UN Assistance Mission in Afghanistan, Kabul.

Yusufzada, S. and Xia, Z. (2019), "Public administration in Afghanistan: challenges and way forward", Open Journal of Social Sciences, Vol. 7 No. 6, pp. 142-160, doi: 10.4236/jss.2019.76012.

\section{Further reading}

Hasanb, N.A., Tak, C. and Bidin, R. (2018), "Job satisfaction among bank employees: an investigation of public banking institution in Malaysia”, Journal Kemanusiaan, Vol. 16, available at: https:// www.researchgate.net/publication/327020121.

Hoppok, R. and Spiegler, S. (1938), "Job satisfaction. Occupations”, The Vocational Guidance Journal, Vol. 16 No. 7, pp. 636-643, doi: 10.1002/j.2164-5892.1938.tb00348.x/abstract.

Kanungo, R.N. (1983), "Work alienation: a pancultural perspective", International Studies of Management and Organization, Vol. 13 No. 1, pp. 119-138, available at: www.jstor.org/stable/ 40396956.

Kumari, G. and Pandey, K.M. (2011), "Job satisfaction in public sector and private sector", International Journal of Innovation, Management and Technology, Vol. 23, pp. 122-128, available at: http://www.ijimt.org/papers/135-M556.pdf.

Mathews, C. and Khann, I.K. (2016), "Impact of work environment on performance of employees in manufacturing sector in India: literature review", International Journal of Science and Research, Vol. 54, pp. 852-855, available at: https://www.ijsr.net/archive/v5i4/NOV162579.pdf.

Nalini, R. (2011), "Social work and the workplace", available at: https://books.google.com.af/books? $\mathrm{id}=8 \mathrm{MAnPOTtAIsCandprintsec}=$ frontcoveranddq $=$ workplaceandhl $=$ enandsa $=$ Xandved $=$ 0ahUKEwjywN-35_PnAhXwyIUKHZQxBrkQ6AEISjAE\#v=onepageandq= workplaceand $\mathrm{f}=$ false.

Pollard, P.L. (2007), "A critical analysis of gender-based workplace challenges facing women: gender and compensation", Forum on Public Policy: A Journal of the Oxford Round Table, Forum on Public Policy, 2007. 
Saif, A.M., Uddin, M.B., Haque, A.A., Rahman, M.M. and Al Mamun, M.A. (2016), "Factors affecting job satisfaction of female employees of private commercial banks in Bangladesh: an empirical investigation", Human Resource Management Research, Vol. 6 No. 3, pp. 65-72, doi: 10.5923/j. hrmr.20160603.02.

Serini, S.A., Toth, E., Wright, D.K. and Emig, A.G. (1995), "Watch for falling glass ...Women, men, and job satisfaction in public relations: a preliminary analysis", Journal of Public Relations Research, Vol. 9 No. 2, pp. 99-118, doi: 10.1207/s1532754xjprr0902_02.

Spector, P.E. (1997), Job Satisfaction: Application, Assessment, Causes, and Consequences, Sage Publications, Thousand Oaks, CA, doi: 10.4135/9781452231549.

Zikmund, G.W., Babin, J.B., Carr, C.J. and Griffin, M. (2009), Business Research Methodes, 8th ed., South-Western College, Nashville, TN.

\section{Corresponding author}

Pierre Rostan can be contacted at: rostan.pierre@gmail.com

For instructions on how to order reprints of this article, please visit our website:

www.emeraldgrouppublishing.com/licensing/reprints.htm

Or contact us for further details: permissions@emeraldinsight.com 